\title{
LICHENS: MIGHT BE CONSIDERED AS A SOURCE OF GASTROPROTECTIVE MOLECULES?
}

\author{
BEATRIZ SEPULVEDA', MARIA CRISTINA CHAMY1, MARISA PIOVANO², CARLOS ARECHE ${ }^{3 *}$ \\ ${ }^{1}$ Departamento de Química, Universidad Andrés Bello, Viña del Mar, Chile \\ ${ }^{2}$ Departamento de Química, Universidad Técnica Federico Santa Maria, Casilla 110-V, Valparaiso, Chile \\ ${ }^{3}$ Departamento de Química, Facultad de Ciencias, Universidad de Chile, Casilla 653, Santiago, Chile \\ (Received: November 13, 2013 - Accepted: March 28, 2013)
}

\begin{abstract}
Lichens are symbiotic relationship between fungi and algae or cyanobacteria. Secondary metabolites from lichens are known as lichen substances. We investigated depsidone and depside from lichens 1-6 in the context of their action to prevent gastric ulcer on the model of $\mathrm{HCl} / \mathrm{ethanol}$ in mice for the first time. Doses of $30 \mathrm{mg} / \mathrm{kg}$ of lichen substances 1-6 and positive control (lansoprazole) significantly diminished the lesion index compared with negative control (treated only with $\mathrm{HCl} / \mathrm{EtOH}$ ). Lobaric acid $\mathbf{1}$, atranorin $\mathbf{2}$ and psoromic acid $\mathbf{5}$ reduced the gastric lesions by $76 \%, 63 \%$ and $65 \%$, while for variolaric acid $\mathbf{3}$, diffractaic acid 4 and perlatolic acid 6 their values were $32 \%, 14 \%$ and $45 \%$, respectively. Our results suggest that lichens have potential as a suite of gastroprotective molecules.
\end{abstract}

Keywords: Lichens; depside; depsidone; gastric ulcer;

\section{INTRODUCTION}

Currently, gastroprotection is defined as the ability of certain endogenous factors and drugs to counteract gastric mucosal damage through mechanisms unrelated to inhibition of acid secretion. It is generally agreed that the gastroprotection depends on the balance between aggressive and defensive mechanisms and that the success of any treatment (gastric ulcers, upper gastrointestinal complications) does not only depend on the blockade of acid secretion but also on the enhancement of mucosal protective mechanisms. ${ }^{1,2}$

Lichens are symbiotic organisms between fungi and algae or cyanobacteria. They occur in a wide range of habitats: from polar to tropical regions, from aquatic to xeric conditions, on the highest mountains, and in extreme environmental conditions (extreme temperatures, high salinity). ${ }^{3}$ Secondary metabolites from lichens are known as lichen substances and are mainly derived from the acetylpolymalonate pathway such as aliphatic acids, depsides, depsones, depsidones, dibenzofurans, usnic acids, xanthones, naphthoquinones, anthraquinones and anthrones. Many lichen substances have a unique range of biological effects such as antioxidant, anti-allergic, anti-inflammatory, analgesic, antipyretic, antimicrobial, insecticidal, antiherbivore, anticancer, antiviral, cytotoxic, UVprotecting agent, and immunomodulatory. ${ }^{3-5}$ However, the effects of psoromic acid, diffractaic acid, atranorin, lobaric acid, perlatolic acid and variolaric acid on the prevention of gastric lesions on the model of $\mathrm{HCl} /$ ethanol in mice has not been investigated to date. Only, diffractaic acid and usnic acid have shown gastroprotective activity in other models. ${ }^{6-7}$

In this study, we report the gastroprotective activity of six known lichen substances from different lichen species collected in diverse localities of Chile Continental and Antarctic, in the $\mathrm{HCl} / \mathrm{EtOH}$-induced gastric lesion model in mice.

\section{EXPERIMENTAL}

\section{Lichens}

The tested metabolites arose from different lichen species collected in diverse localities of Chile continental and Antarctic. The orcinol depsidone lobaric acid 1 was isolated from Stereocaulon alpinum Laur. collected in Robert Island and in Ardley Cove ( King George Island), Antarctic. ${ }^{8}$ Atranorin 2, an $\mathrm{b}$-orcinol depside, was obtained from Buellia cladocarpisa Lamb. collected in Copper Mine Cove, Robert Island, Shetland del Sur, Antarctic. ${ }^{8}$ The depsidone variolaric acid $\mathbf{3}$ isolated from Ochrolechia deceptionis Hue. collected in King George Island, near Marsh Base, Antarctic. ${ }^{9}$ From Protousnea magellanica (Mont) Krog collected in Laguna Icalma, IX Region, Chile was isolated diffractaic acid 4. ${ }^{10}$ The lichen depsidone psoromic acid $\mathbf{5}$ was obtained from Ingaderia pulcherrima Darb. collected at Pan de Azúcar National Park, III Region, Chile. ${ }^{11}$ Perlatolic acid $\mathbf{6}$ obtained from Stereocaulon $s p$. collected in Parque Nacional Puyehue, X Region, Chile.

Extraction, isolation and identification of lichen compounds

This lichen compounds were obtained as has already been reported. ${ }^{8-11}$ The compounds 1-6 were dissolved in $0.8 \mathrm{~mL}$ of $\mathrm{CD}_{3} \mathrm{COCD}_{3}$ containing tetramethylsilane (TMS) as internal standard. ${ }^{1} \mathrm{H}-\mathrm{NMR}$ spectra were measured at $400.13 \mathrm{MHz}$ on a Bruker instrument and chemical shift (d) reported in ppm.

The ${ }^{1} \mathrm{H}-\mathrm{NMR}$ spectrum of $\mathbf{1}$ indicated the presence of three aromatic signals at $\delta 7.03(1 \mathrm{H}, \mathrm{d}, J=2.2), 7.02(1 \mathrm{H}, \mathrm{d}, J=2.2)$ and $6.78(1 \mathrm{H}, \mathrm{s})$; a methoxy group at $\delta 3.98(3 \mathrm{H}, \mathrm{s})$; three methylene protons at $\delta 3.25(2 \mathrm{H}, \mathrm{m}$, -CO), 2.86 (2H, m, -phenyl) and 1.39-1.63 (10H, -aliphatic); and two methyl groups signals at $\delta 0.92(3 \mathrm{H}, \mathrm{t}, J=7.3), 0.91(3 \mathrm{H}, \mathrm{t}, J=7.3)$. These signals are characteristic of lobaric acid. ${ }^{12}$

The compound 2 was established as follows: The ${ }^{1} \mathrm{H}-\mathrm{NMR}$ spectrum showed signals for three $\mathrm{H}-\mathrm{O}$ phenolic at $\delta 12.5(1 \mathrm{H}, \mathrm{s}), 12.3(1 \mathrm{H}, \mathrm{s}), 11.9$ $(1 \mathrm{H}, \mathrm{s})$; for an aldehyde proton at $\delta 10.4(1 \mathrm{H}, \mathrm{s})$; for two aromatic protons at $\delta$ $6.77(1 \mathrm{H}, \mathrm{s})$ and $6.51(1 \mathrm{H}, \mathrm{s})$; along with a methyl ester at $\delta 4.02(3 \mathrm{H}, \mathrm{s})$ and three methyl groups at $\delta 2.70(3 \mathrm{H}, \mathrm{s}), 2.55(3 \mathrm{H}, \mathrm{s})$ and $2.09(3 \mathrm{H}, \mathrm{s})$. These data showed that this compound is atranorin. ${ }^{12}$

The ${ }^{1} \mathrm{H}-\mathrm{NMR}$ spectrum of $\mathbf{3}$ showed three aromatic protons at $\delta 6.98(1 \mathrm{H}$, s), $6.88(1 \mathrm{H}, \mathrm{d}, J=1.9)$ and $6.73(1 \mathrm{H}, \mathrm{d}, J=1.9)$; a methylene singlet at high field $(\delta 5.28)$ and a methyl group at $\delta 2.41(3 \mathrm{H}, \mathrm{s})$. These data are consistent with variolaric acid. ${ }^{13}$

Diffractaic acid 4 showed two aromatic signals at $\delta 6.76(1 \mathrm{H}, \mathrm{s})$ and 6.68 $(1 \mathrm{H}, \mathrm{s})$ in the ${ }^{1} \mathrm{H}-\mathrm{NMR}$ spectrum, along with two methoxy groups at $\delta 3.89(3 \mathrm{H}$, s), $3.83(3 \mathrm{H}, \mathrm{s})$ and four singlet methyls at $\delta 2.62(3 \mathrm{H}, \mathrm{s}), 2.44(3 \mathrm{H}, \mathrm{s}), 2.14$ $(3 \mathrm{H}, \mathrm{s})$ and $2.13(3 \mathrm{H}, \mathrm{s}) .6,10$

The ${ }^{1} \mathrm{H}$-NMR spectrum of psoromic acid $\mathbf{5}$ showed signals for an aldehyde group at $\delta 10.58(1 \mathrm{H}, \mathrm{s})$; for two aromatic protons at $\delta 7.22(1 \mathrm{H}, \mathrm{s})$ and 6.79 $(1 \mathrm{H}, \mathrm{s})$; for a methoxy group at $\delta 3.93(3 \mathrm{H}, \mathrm{s})$ and signals at $\delta 2.52(3 \mathrm{H}, \mathrm{s})$ and $2.26(3 \mathrm{H}, \mathrm{s})$ due to two methyls. ${ }^{14}$

Perlatolic acid 6 in the ${ }^{1} \mathrm{H}-\mathrm{NMR}$ spectrum showed four aromatic protons at $\delta 6.79(1 \mathrm{H}, \mathrm{d}, J=2.4), 6.76(1 \mathrm{H}, \mathrm{d}, J=2.4), 6.47(1 \mathrm{H}, \mathrm{d}, J=2.4)$ and $6.41(1 \mathrm{H}$, $\mathrm{d}, J=2.4) ;$ a methoxy group at $\delta 3.86 \mathrm{~s}$; and two penthyl groups at almost the same resonance $(\delta 3.03,2.97,1.67$ and 1.35 for methylene protons and 0.89 , 0.86 for methyl groups). ${ }^{15}$

Animals

Animals were purchased from the Instituto de Salud Pública de Chile, Santiago. Swiss albino mice weighing $30 \pm 3 \mathrm{~g}$ were fasted for $24 \mathrm{~h}$ prior to the experiment. The animals were fed on certified Champion diet with free access to water under standard conditions of $12 \mathrm{~h}$ dark-light period, $50 \%$ relative humidity and $22{ }^{\circ} \mathrm{C}$ room temperature. The protocols were approved by the Animal Use and Care Committee of the Universidad de Chile that follows the recommendations of the Canadian Council on Animal Care and with the ethical guidelines for investigations in conscious animal. ${ }^{16}$

$\mathrm{HCl} /$ Ethanol-induced gastric lesions and treatments

The gastroprotective activity of compounds 1-6 was assessed as described previously. ${ }^{17,18}$ Mice were allotted into groups of eight animals each. Fifty min after oral administration of lichen substances 1-6 (30 mg/kg), lansoprazole (30 $\mathrm{mg} / \mathrm{kg}$, Sigma-Aldrich USA) or $1 \%$ Tween 80 (negative control or vehicle, Merck, Germany), were orally treated with $0.2 \mathrm{ml}$ of a solution containing $0.3 \mathrm{M} \mathrm{HCl} / 80 \%$ ethanol for gastric lesion induction. Animals were sacrificed 1 $\mathrm{h}$ after the administration of $\mathrm{HCl} /$ ethanol, and the stomachs were excised and inflated by injection of saline $(2 \mathrm{ml})$. The ulcerated stomachs were fixed in $5 \%$ formalin for $30 \mathrm{~min}$ and opened along the greater curvature. Gastric damage 
visible to the naked eye was observed in the gastric mucosa as elongated blackred lines, parallel to the long axis of the stomach similar to the $\mathrm{HCl} /$ ethanolinduced lesions in rats. The length $(\mathrm{mm})$ of each lesion was measured, and the lesion index was expressed as the sum of the length of all lesions.

\section{Statistical analysis}

Results were expressed as the mean \pm S.D. In all experiments, statistical differences between several treatments and their respective control were determined by one-way analysis of variance (ANOVA) followed by the Dunnett's multiple comparison tests. The level of significance was set at $P$ $<0.01$. All statistical analyses were performed using the software GraphPad Prism 4 for Windows.

\section{RESULTS AND DISCUSSION}

The chemical structures of the compounds 1-6 are shown in Figure 1.
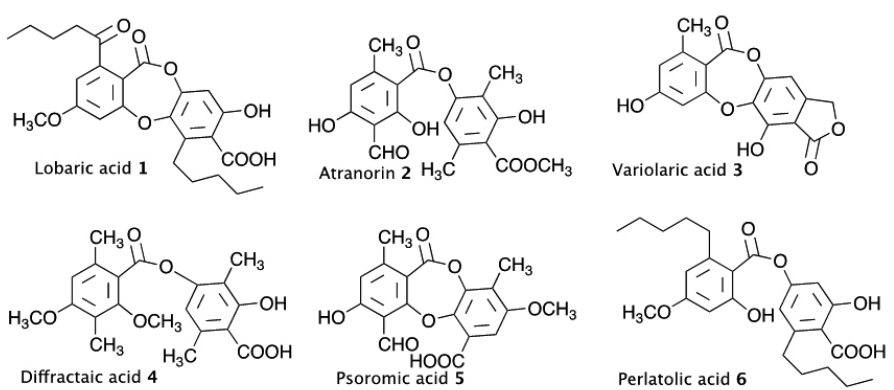

Fig. 1 Chemical structure of six compounds isolated from lichens.

In the present study, the gastroprotective effect of lichen substances 1-6 was evaluated in a model of gastric damage elicited by application of an ethanol/HCl solution in mice. Compounds $\mathbf{1 - 6}$ clearly decreased the gastric lesions at $30 \mathrm{mg} / \mathrm{kg}$ (Table 1). The inhibition displayed by lobaric acid (1, $76 \%)$, atranorin $(2,63 \%)$ and psoromic acid $(5,65 \%)$ were similar to that observed with lansoprazole $(69 \%)$, while for variolaric acid $\mathbf{3}$, diffractaic acid 4 and perlatolic acid 6 their values were $32 \%, 14 \%$ and $45 \%$ respectively.

Table 1 Gastroprotective effect of lansoprazole and the lichen substances 1-6 on $\mathrm{HCl} / \mathrm{EtOH}$-induced gastric lesions in mice.

\begin{tabular}{|c|c|c|c|c|c|}
\hline Compounds & $\begin{array}{c}\text { Dose } \\
(\mathrm{mg} / \mathrm{kg})\end{array}$ & $N$ & $\begin{array}{c}\text { Lesion } \\
\text { index }(\mathrm{mm})\end{array}$ & $\begin{array}{c}\% \\
\text { Inhibition }\end{array}$ & $p$ \\
\hline $\mathbf{1}$ & 30 & 8 & $8.42 \pm 2.6$ & 76 & $<0.01$ \\
\hline $\mathbf{2}$ & 30 & 8 & $13.57 \pm 3.3$ & 63 & $<0.01$ \\
\hline $\mathbf{3}$ & 30 & 8 & $24.71 \pm 3.5$ & 32 & $<0.01$ \\
\hline $\mathbf{4}$ & 30 & 8 & $31.29 \pm 3.5$ & 14 & $<0.05$ \\
\hline $\mathbf{5}$ & 30 & 8 & $12.86 \pm 1.8$ & 65 & $<0.01$ \\
\hline $\mathbf{6}$ & 30 & 8 & $19.86 \pm 4.0$ & 45 & $<0.01$ \\
\hline Lansoprazole & 30 & 7 & $11.14 \pm 3.8$ & 69 & $<0.01$ \\
\hline Vehicle & - & 7 & $36.14 \pm 4.3$ & - & $<0.01$ \\
\hline Healthy group & - & 6 & - & - & - \\
\hline
\end{tabular}

Results are expressed as mean \pm sd. $P<0.05$ or $P<0.01$ significantly different compared with the control (ANOVA followed by Dunnett's test). $N$ $=$ animal number.

Some gastroprotective metabolites from lichens are active at different oral doses in rats. Bayir et al. (2006) ${ }^{6}$ studied the antiulcerogenic activity of $\mathbf{4}$ on indomethacin-induced gastric lesions in rat as well as the activities of the antioxidant enzymes as superoxide dismutase, catalase, glutathione peroxidase, and the level of reduced glutathione and lipid peroxidation. In that study, diffractaic acid at $25,50,100$ and $200 \mathrm{mg} / \mathrm{kg}$ reduced the ulcer index by $43.5 \%, 52.9 \%, 91.4 \%$ and $96.7 \%$, respectively. Therefore, Bayir et al. (2006) showed that $\mathbf{4}$ had significant gastroprotective activity and it was attributed to an enhancing on antioxidant defense systems.

Other study of the antiulcerogenic activity of usnic acid, one of the most common and abundant lichen substances, has been reported. ${ }^{7}$ In indomethacininduced gastric lesions in rat, usnic acid reduced the gastric lesions by $92.9 \%$,
$80.2 \%, 96.4 \%$ and $88.3 \%$ at $25,50,100$ and $200 \mathrm{mg} / \mathrm{kg}$, respectively. They concluded that the gastroprotective activity of usnic acid was due to its reducing effect against oxidative damage and its inhibitory effect on neutrophil infiltration in stomach rat tissues.

It is well known that ethanol/ $\mathrm{HCl}$ evoke acute tissue damage, oxidative damage, hemorrhages, cellular exfoliation, infiltration by inflammatory cells and generation of ROS. ${ }^{19}$ Our results showed that compound 1, 2 and 5 exhibited significant gastroprotective activity at $30 \mathrm{mg} / \mathrm{kg}$. Lobaric acid 1 showed the best gastroprotective effect while diffractaic acid $\mathbf{4}$ presented the lowest gastroprotective activity in our study. However, their effects of $\mathbf{4}$ cannot be compared than other studies since both models have mechanisms different. Compound $\mathbf{4}$ at $25 \mathrm{mg} / \mathrm{kg}$ reduced the gastric lesion by $43.5 \%$ on indomethacin-induced gastric lesions in rat, ${ }^{6}$ while at $30 \mathrm{mg} / \mathrm{kg}$ reduced the lesions by $14 \%$ on the model of $\mathrm{HCl} /$ ethanol in mice.

Some extracts from lichen species have showed to reduce the gastric lesions in other models. For instance, water-ethanol extract of Ramalina capitata showed gastroprotective activity at $200 \mathrm{mg} / \mathrm{kg}$ on the indomethacin-induced gastric lesion model in rats. The authors suggested that the gastroprotective activity displayed by the extracts could be attributed to the antioxidant activity. ${ }^{20}$ Karakus et al. (2009) ${ }^{21}$ reported the gastroprotective effect of the methanol extract of Lobaria pulmonaria against indomethacin-induced gastric lesions. It was suggested that the gastroprotective effect could be due to reducing oxidative stress and neutrophil infiltration. Other study includes the antiulcerogenic and antioxidant effect at 50,100 and $200 \mathrm{mg} / \mathrm{kg}$ of a water extract from Usnea longissima, which it was attributed to its antioxidant potential. ${ }^{22}$ On the other hand, some alkaloids, flavonoids, terpenoids or their derivatives have been shown to have gastroprotective properties. Some reviews have been published whose discussion is related the chemical nature and mechanism of action of natural products as gastroprotective agents. ${ }^{23-26}$ Gastroprotective compounds seem to work mainly stimulating the defensive factor in the gastric mucosa rather than inhibiting the aggressive factors such as pepsin or gastric acid. Further studies are needed to assess the action mechanisms of the lichen substances. However, additional work should be undertaken to isolate other compounds from lichens and to assess their gastroprotective effects.

In conclusion, several pharmacological activities have been reported during the last 25 years for lichen substances but none related with gastroprotective activity using the model of $\mathrm{HCl} /$ ethanol-induced gastric lesions in mice.

\section{ACKNOWLEDGEMENTS}

Financial support by Fondecyt de Iniciación No 11110241.

\section{REFERENCES}

1. S. Szabo, I. Goldberg, Scand. J. Gastroenterol. 174, 1, (1990)

2. H. Suleyman, A. Albayrak, M. Bilici, E. Cadirci, Z. Halici, Inflammation 22, 224, (2010)

3. N.K. Honda, W. Vilegas, Quim. Nova. 21, 110, (1998)

4. K. Molnár, E. Farkas, Z. Naturforsch. C 65, 157, (2010)

5. V. Shukla, G.P. Joshi, M.S.M. Rawat, Phytochem. Rev. 9, 303, (2010)

6. Y. Bayir, F. Odabasoglu, A. Cakir, A. Aslam, H. Suleyman, M. Halici, C. Kazaz, Phytomedicine 13, 584, (2006)

7. F. Odabasoglu, A. Cakir, H. Suleyman, A. Aslan, Y. Bayir, M. Halici, C. Kazaz, J. Ethnopharmacol. 103, 59, (2006)

8. W. Quilhot, J.A. Garbarino, M. Piovano, M.C. Chamy, V. Gambaro, M.L. Oyarzún, C. Vinet, V. Hormaechea, Ser. Cient. INACH 39, 75, (1989)

9. M. Piovano, J.A. Garbarino, M.C. Chamy, V. Zúñiga, C. Miranda, E. Céspedes, P. Fiedler, W. Quilhot, G. Araya, Ser. Cient. INACH 41, 79, (1991)

10. J.A. Garbarino, M.C. Chamy, V. Gambaro, W. Quilhot, O. Naranjo, E. Bolt, J. Nat. Prod. 50, 745, (1987)

11. M. Piovano, M.C. Chamy, P. Fiedler, J.A. Garbarino, C. Cárcamo, W. Quilhot, Bol. Soc. Chil. Quim. 38, 183, (1993)

12. K. Ingolfsdottir, S.R. Gissurarson, B. Müller-Jakic, W. Breu, H. Wagner, Phytomedicine 2, 243, (1996)

13. J.P. Devlin, C.P. Falshaw, W.D. Ollis, R.E. Wheeler, J. Chem. Soc. C. 1318, (1971)

14. T. Sala, M.V. Sargent, J. C. S. Perkin I 2593, (1979)

15. C.F. Culberson, Phytochemistry 9, 841, (1970)

16. E.D. Olfert, B.M. Cross, A.A. McWilliam, Canadian Council on Animal Care, Ottawa, Ontario, 1, 1, (1993)

17. E. Yesilada, I. Gurbuz, E. Ergun, J. Ethnopharm. 55, 201, (1997) 
18. A.R. Souza-Brito, J.A. Rodriguez, C. Hiruma-Lima, M. Haun, D. Nunes, Planta Med. 64, 126, (1998)

19. S. Kwicien, T. Brzozowski, S.J. Konturek, J. Physiol. Pharmacol. 53, 39, (2002)

20. M. Halici, O.I. Kufrevioglu, F. Odabasoglu, Z. Halici, A. Cakir, A. Aslan, J. Food Biochem. 35, 11, (2011)

21. B. Karakus, F. Odabasoglu, A. Cakir, Z. Halici, Y. Bayir, M. Halici, A. Aslan, H. Suleyman, Phytother. Res. 23, 635, (2009)

22. M. Halici, F. Odabasoglu, H. Suleyman, A. Cakir, A. Aslan, Y. Bayir, Phytomedicine 12, 656, (2005)
23. D.A. Lewis, D. Hanson, In Progress in Medicinal Chemistry, G.P. Ellis, G.B. West, Eds. Elsevier Science, Amsterdam, (1991); pp. 201-231.

24. R. Tundis, M.R. Loizzo, M. Bonesi, F. Menichini, F. Conforti, G. Statti, F. Menichini, Nat. Prod. Comm. 3, 2129, (2008)

25. K.S. Mota, G.E. Dias, M.E. Pinto, A. Luis-Ferreira, A.R. Souza-Brito, C.A. Hiruma-Lima, J.M. Barbosa-Filho, L.M. Batista, Molecules 14, 979, (2009)

26. S. Sumbul, M.A. Ahmad, M. Asif, M. Akhtar, J. Pharm. and Bioallied Sci. 3, 361, (2011) 